\title{
Aspirin-Triggered Lipoxins (15-epi-LX) Are Generated by the Human Lung Adenocarcinoma Cell Line (A549)- Neutrophil Interactions and Are Potent Inhibitors of Cell Proliferation
}

\author{
Joan Clària, ${ }^{1}$ Min H. Lee, and Charles N. Serhan \\ Center for Experimental Therapeutics and Reperfusion Injury, \\ Department of Anesthesia, Brigham and Women's Hospital and \\ Harvard Medical School, Boston, Massachusetts, U.S.A.
}

\begin{abstract}
Background: The mechanism by which aspirin (ASA) acts to protect against human cancer is not yet known. We recently showed that ASA triggers the formation of a new series of potent bioactive eicosanoids, 15-epi-lipoxins (15-epi-LXs or ASA-triggered LX [ATL]), during interactions between prostaglandin endoperoxide synthase-2 (PGHS-2) in endothelial cells and 5-lipoxygenase (LO) in leukocytes. Here, we investigated the transcellular biosynthesis of these eicosanoids during costimulation of the human tumor A549 cell line (alveolar type II epithelial cells) and neutrophils, and evaluated their impact on cell proliferation.

Materials and Methods: A549 cells and isolated neutrophils were coincubated and mRNA expression levels of key enzymes in eicosanoid biosynthesis were measured. In addition, product formation was analysed by physical methods. The effect of LX on cell proliferation was determined by using a soluble microculture tetrazolium (MTT) assay and by measuring $\left[{ }^{3} \mathrm{H}\right]$-thymidine incorporation.

Results: Interleukin-1 $\beta$ (IL-1 $\beta$ )-primed A549 cells showed selective elevation in the levels of PGHS-2 mRNA and generated 15-hydroxyeicosatetraenoic acid (15-HETE). ASA markedly increased 15-HETE formation by A549 cells, while treatment with an inhibitor of cytochrome $\mathrm{P} 450$ reduced by $\sim 50 \%$, implicating both PGHS-2- and cytochrome P450-initiated routes in 15 -
\end{abstract}

HETE biosynthesis in these cells. Maximal production of 15-HETE from endogenous sources occurred within 24 hr of cytokine $(\mathrm{IL}-1 \beta)$ exposure and declined thereafter. Chiral analysis revealed that $\sim 85 \%$ of ASA-triggered epithelial-derived 15-HETE carries its carbon 15 alcohol group in the $R$ configuration. Costimulation of ASAtreated A549 cells and polymorphonuclear neutrophilic leukocytes (PMN) led to production of both $\mathrm{LXA}_{4}$ and $\mathrm{LXB}_{4}$, as well as 15-epi-LXA 4 and 15-epi-LXB $\mathrm{LX}_{4}$ (9.5 \pm $0.5 \mathrm{ng} \mathrm{LX} / 10^{7}$ A549 cells). 15-epi-LXA $\mathrm{LAc}_{4}$ accounted for $\sim 88 \%$ of the total amount of $\mathrm{LXA}_{4}$ produced. In addition to LXs, stimulation of A549 cells and PMN also liberated substantial amounts (77.2 $\pm 8.2 \mathrm{ng} / 10^{7} \mathrm{~A} 549$ cells) of peptidoleukotrienes (pLTs), which were not generated by either cell type alone. Addition of ASA to these co-incubations led to an increase in the amounts of LXs generated that was paralleled by a decrease in pLTs. $\mathrm{LXA}_{4}, \mathrm{LXB}_{4}, 15$-epi-LXA 4 and 15-epi-LXB ${ }_{4}$, as well as dexamethasone, inhibited cell proliferation at $100 \mathrm{nM}$ range with a rank order of activity of 15 -epi- $\mathrm{LXB}_{4}>>>$ $\mathrm{LXB}_{4}>$ dexamethasone $\geq 15$-epi-LXA $\mathrm{LXX}_{4}>\mathrm{LXA}_{4}$. Conclusions: These results indicate that ASA promotes the formation of antiproliferative 15-epi-LXs by epithelial cell-leukocyte interactions. Moreover, they suggest that these novel eicosanoids, when generated within the microenvironment of tissues, may contribute to ASA's therapeutic role in decreasing the risk of human cancer.

\section{INTRODUCTION}

Alveolar epithelial cells constitute the vast airtissue interface of the distal lung and are strate-

Address correspondence and reprint requests to: Charles $\mathbf{N}$. Serhan, Center for Experimental Therapeutics and Reperfusion Injury, Brigham and Women's Hospital, 75 Francis Street, Boston, MA 02115 , U.S.A.

${ }^{1}$ Present address: Hospital Clínic i Provincial, Universitat de Barcelona, Villarroel 170, Barcelona 08036, Spain. gically located to interact with substances or cells in both the alveolar space and the pulmonary interstitium. These cells play an active role in the immune response by their ability to generate biologically active mediators in response to stimuli (1). In this regard, airway epithelial cells may also interact with leukocytes that have been recruited from peripheral blood to the lung interstitium to produce new mediators by transcellu- 
lar routes. We hypothesized that lipid mediators generated during these cell-cell interactions within the local microenvironment may serve homeostatic functions and also modulate pathophysiological pulmonary changes such as hyperplasia, fibrosis, and neoplasia.

Lipoxins (LXs) are eicosanoids (a class of compounds derived from polyunsaturated fatty acids, such as arachidonic acid) that carry a conjugated tetraene structure and biological activities that clearly distinguish them from other eicosanoids such as prostaglandins (PGs) and leukotrienes (LTs) (2). In human tissues, LX formation occurs predominantly by cell-cell interactions and two established routes of transcellular LX biosynthesis have been identified to date. These include oxygenation of arachidonic acid by 15-lipoxygenase (15-LO) followed by formation of a 5(6)-epoxytetraene intermediate in leukocytes to give $\mathrm{LXA}_{4}$ and $\mathrm{LXB}_{4}(15-\mathrm{H}(\mathrm{p})$ ETE pathway) and/or transformation of leukocyte-derived $\mathrm{LTA}_{4}$ to $\mathrm{LXs}$ by platelet $12-\mathrm{LO}\left(\mathrm{LTA}_{4}\right.$ : 12-LO pathway). LX generated by these two pathways carry their $\mathrm{C} 15$ alcohol in the $S(>85-$ $90 \%$ ) configuration (reviewed in Ref. 3). Recently, a new biosynthetic route of transcellular LX formation was identified (4). This pathway is triggered by aspirin (ASA) and involves the formation of a key intermediate from arachidonic acid, namely 15- $R$-15-hydroxy-eicosatetraenoic acid (15R-HETE), by ASA-acetylated prostaglandin endoperoxide synthase-2 (PGHS-2, cyclooxygenase). In cytokine-treated endothelial cells, this intermediate is released and transformed in activated human leukocytes by 5 -LO and subsequent reactions to produce a new series of 15epimeric LXs (ASA-PGHS-2 pathway).

Evidence is accumulating that ASA has a protective role against human cancer (5). The mechanism by which ASA acts to reduce the incidence and risk of human cancers (including lung, colon, and breast cancers) is not yet known but may be related to its ability to inhibit PGHSdependent PG biosynthesis (for review see Ref. 6). Given that ASA does not directly affect LO enzymes (2), eicosanoids generated by transcellular biosynthesis in the presence of ASA (i.e., 15-epi-LXs and LX), may be involved in ASA's newly uncovered chemopreventive therapeutic actions $(4,7)$. Here, we report that ASA stimulates the formation of 15-epi-LXs from the tumor-derived (A549 cells) epithelial cell-PMN interactions and provide evidence for the role of these eicosanoids, in particular 15 -epi- $\mathrm{LXB}_{4}$, in inhibiting cell proliferation. Moreover, this is the first report both of formation and of a specific bioaction for 15-epi- $\mathrm{LXB}_{4}$.

\section{MATERIALS AND METHODS}

\section{Materials}

Synthetic $(5 S, 6 R, 15 R)$-trihydroxy-7,9,13-trans11-cis-eicosatetraenoate:carboxymethyl ester (15-epi-LXA 4 -methyl ester) was prepared by total organic synthesis and was a gift of Prof. N. A. Petasis (Department of Chemistry, University of

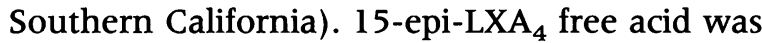
obtained by saponification of 15-epi-LXA ${ }_{4}^{-}$ methyl ester in tetrahydrofuran with $\mathrm{LiOH}(0.1$ M) at $4^{\circ} \mathrm{C}$ for $24 \mathrm{hr}$. Synthetic eicosanoid reference samples were from Cascade Biochem Ltd. (Reading, Berkshire, England). Inhibitors of 5-lipoxygenase (Rev 5901 isomer) and cytochrome P450 (17-octadecaynoic acid, 17-ODYA) activities were from Biomol (Plymouth Meeting, PA, U.S.A.). Radiolabeled $\left(\left[{ }^{32} \mathrm{P}\right]\right)$ dCTP and $\left(\left[{ }^{3} \mathrm{H}\right]\right)$ arachidonic acid and methyl-thymidine were from Dupont NEN (Boston, MA, U.S.A.). Ionophore $\left(\mathrm{A}_{23187}\right)$, ASA, 3,(4,5-dimethylthiazoyl-2yl) 2,5(diphenyl-tetrazolium bromide) (MTT), and guanidinium isothyocyanate were purchased from Sigma Chemical Co. (St. Louis, MO, U.S.A.). Recombinant human interleukin-1 $\beta$ (IL-1 $\beta$ ) was obtained from R\&D Systems (Minneapolis, MN, U.S.A.). Dulbecco's phosphatebuffered saline containing both $\mathrm{CaCl}_{2}(0.6 \mathrm{mM})$ and $\operatorname{MgCl}_{2}(1.0 \mathrm{mM})(\mathrm{pH} 7.4)\left(\mathrm{DPBS}^{2+}\right)$, fetal bovine serum (FBS), penicillin, and streptomycin were from Bio Whittaker (Walkersville, MD, U.S.A.). Hanks' balanced salt solution (HBSS) and $\mathrm{F}-12 \mathrm{~K}$ nutrient mixture were from Gibco Laboratories (Grand Island, NY, U.S.A.). Highpressure liquid chromatography (HPLC) grade solvents and cesium chloride were purchased from JT Baker (Phillipsburg, NJ, U.S.A.), methyl formate was from Eastman Kodak Co. (Rochester, NY, U.S.A.) and Sep-Pak $\mathrm{C}_{18}$ cartridges were from Waters Associates (Milford, MA, U.S.A.). Diazomethane was prepared from N-methyl- $\mathrm{N}^{\prime}$ nitro-N-nitroguanidine purchased from Aldrich Chemical Co. (Milwaukee, WI, U.S.A.). N,0-bis (trimethylsilyl) trifluoroacetamide (BSTFA) was from Pierce (Rockford, IL, U.S.A.). First strand cDNA synthesis kit and other molecular biology reagents were from Promega (Madison, WI, U.S.A.). Oligonucleotide primers were purchased from Integrated DNA Technologies (Coralville, IA, U.S.A.). 


\section{Cell Isolation and Culture}

Human type II epithelial A549 cells from human lung carcinoma and normal human skin fibroblast (breast) were obtained from the American Type Culture Collection (Rockville, MD, U.S.A.). The A549 cell line originates from a human alveolar cell carcinoma and has proven to be a useful cell line because they are easily assessable and are maintained in culture without contaminating tissue macrophages (8). Fibroblasts were utilized within their limited window of viability and their passage numbers were recorded (results are reported for cells from three to five passages). Epithelial A549 cells were seeded into $\mathrm{T}-75 \mathrm{~cm}^{2}$ tissue culture flasks and maintained in F-12K medium supplemented with $10 \%$ heatinactivated FBS, penicillin $(50 \mathrm{U} / \mathrm{ml})$, and streptomycin $(50 \mu \mathrm{g} / \mathrm{ml})$. Human PMN from healthy donors who had not taken ASA or other medications for at least 2 weeks were obtained by Ficoll-Hypaque gradient centrifugation and dextran sedimentation (9) and suspended in DPBS ${ }^{+}$ at pH 7.4. Viability of A549 cells and PMN was determined by their ability to exclude trypan blue and were $95 \pm 2 \%$ and $97 \pm 1 \%$, respectively. These values were not significantly altered during the reported incubations.

\section{Incubation Conditions}

In incubations involving permeabilized A549 cells (prepared by a rapid freeze-thaw cycle), IL- $1 \beta$-treated $(1 \mathrm{ng} / \mathrm{ml}, 24 \mathrm{hr}$ ) A549 cells $(1.5 \times$ $10^{6}$ cells $/ \mathrm{ml}$ ) were pretreated for $20 \mathrm{~min}$ with either vehicle $(0.1 \% \mathrm{EtOH})$, ASA $(500 \mu \mathrm{M}$; used throughout), $5 \mu \mathrm{M}$ 17-ODYA, an inhibitor of cytochrome P450 (10), or 5 mM Rev 5901 isomer, a 5-LO inhibitor, subjected to two cycles of rapid freezing in a dry ice-acetone bath and thawing to room temperature (full cycle $<20$ min), and incubated with arachidonic acid (20 $\mu \mathrm{M})$ for $20 \mathrm{~min}$ at $37^{\circ} \mathrm{C}$ in $4 \mathrm{ml}$ of $\mathrm{DPBS}^{2+}$. In experiments involving radiolabeled arachidonic acid, incubations were initiated with the addition of $\left[{ }^{3} \mathrm{H}\right]$-arachidonic acid $(0.25 \mu \mathrm{Ci} / \mathrm{ml})$ plus unlabeled arachidonic acid $(20 \mu \mathrm{M})$ for $20 \mathrm{~min}$ at $37^{\circ} \mathrm{C}$.

For time course experiments involving the generation of 15-HETE from endogenous sources (Fig. 2B), intact A549 cells were exposed to IL-1 $\beta$ ( $1 \mathrm{ng} / \mathrm{ml}$ ) for up to $48 \mathrm{hr}$ and then treated with vehicle (containing $0.1 \% \mathrm{EtOH}$ ) or ASA for 20 min followed by addition of ionophore $A_{23187}(5$ $\mu \mathrm{M}$ ) in $4 \mathrm{ml}$ of HBSS for $30 \mathrm{~min}$ at $37^{\circ} \mathrm{C}$.

In co-incubation experiments, confluent
A549 cells were exposed to IL- $1 \beta$ ( $1 \mathrm{ng} / \mathrm{ml}, 24$ $\mathrm{hr}$ ), washed in HBSS and treated with vehicle alone or ASA for $20 \mathrm{~min}$ and arachidonic acid $(20 \mu \mathrm{M})$ for $60 \mathrm{sec}$ at $37^{\circ} \mathrm{C}$. Co-incubations were performed by adding PMN to A549 cell monolayers followed by costimulation with ionophore $\mathrm{A}_{23187}(5 \mu \mathrm{M})$ in $4 \mathrm{ml}$ of HBSS for $30 \mathrm{~min}$ at $37^{\circ} \mathrm{C}$.

\section{Analysis of Eicosanoids}

Incubations were stopped with two volumes of cold $\mathrm{MeOH}$ containing prostaglandin $\mathrm{B}_{2}(200 \mathrm{ng})$ and products were extracted using Sep-Pak $C_{18}$ cartridges. Materials that eluted in the methyl formate fractions were concentrated under a stream of $\mathrm{N}_{2}$ and scanned for ultraviolet (UV)absorbing material (in methanol) with a Model 8452 spectrophotometer (Hewlett Packard Co., Palo Alto, CA, U.S.A.) prior to injection into a reversed phase (RP)-HPLC system. This system consisted of a dual pump gradient (LKB, Bromma, Sweden), a diode array detector (Hewlett-Packard 1040M series II) and a HPLC ${ }^{3 D}$ ChemStation software. The collected UV data were recalled at $300 \mathrm{~nm}$ to monitor conjugated tetraenes, at $270 \mathrm{~nm}$ for trienes, and 234 for monoHETEs. All UV spectra were acquired using step $=4 \mathrm{~nm}, \mathrm{Bw}=10 \mathrm{~nm}$, and range $=220-360$ $\mathrm{nm}$ with a sampling interval of $0.96 \mathrm{sec}$.

The monohydroxy eicosanoids (i.e., 5-, 12-, and 15-HETE) from A549 cells were analyzed using a Ultrasphere-ODS column $(5 \mu \mathrm{m}, 4.6$ $\mathrm{mm} \times 25 \mathrm{~cm}$ ) (Beckman Instruments, Fullerton, CA, U.S.A.) was eluted with $\mathrm{MeOH} / \mathrm{H}_{2} \mathrm{O} /$ acetic acid $(65: 35: 0.01 ; \mathrm{v} / \mathrm{v} / \mathrm{v})$ as phase one $\left(t_{0}-20\right.$ $\mathrm{min})$, and a linear gradient with $\mathrm{MeOH} /$ acetic acid (99.99:0.01, v/v) as phase two (20-45 min) at a flow rate of $1.0 \mathrm{ml} / \mathrm{min}$. The $R$ - and $S$ enantiomers of 15-HETE were resolved and identified using a chiral HPLC system similar to that reported by Hawkins et al. (11). Briefly, after RP-HPLC material eluting beneath 15-HETE peak was extracted with chloroform and converted into methyl ester by ethereal diazomethane treatment. Chiral analysis was performed with a Bakerbond DNBPG (covalent) chiral column $(5 \mu \mathrm{m}, 4.6 \mathrm{~mm} \times 25 \mathrm{~cm})$ (JT Baker, Phillipsburg, NJ, U.S.A.) eluted with $n$-hexane/2propanol $(100: 0.4 ; \mathrm{v} / \mathrm{v})$ at a flow rate of 0.8 $\mathrm{ml} / \mathrm{min}$. When indicated, generation of 15 -HETE from endogenous sources was monitored by radioimmunoassay (RIA). The antibody was raised against $15 S$-HETE with $0.1 \%$ cross-reactivity at $50 \% \mathrm{~B} / \mathrm{B}_{0}$ for 5 -HETE (PerSeptive Diagnostics, Cambridge, MA, U.S.A.). 
For analysis of lipoxins (including LXs and 15-epi-LX) from A549 cell-PMN, co-incubations were carried out using either a Waters $\mu$ Bondapak $\mathrm{C}_{18}(3.9 \times 300 \mathrm{~nm})$ column eluted with an isocratic mobile phase $\mathrm{MeOH} / \mathrm{H}_{2} \mathrm{O}$ /acetic acid $(60: 40: 0.01 ; \mathrm{v} / \mathrm{v} / \mathrm{v})$ with a flow rate of 0.6 $\mathrm{ml} / \mathrm{min}$ or an Altex Ultrasphere ODS column $(5$ $\mu \mathrm{m}, 10 \mathrm{~mm} \times 25 \mathrm{~cm}$ ) eluted with $\mathrm{MeOH} / \mathrm{H}_{2} \mathrm{O} /$ acetic acid $(65: 35: 0.01 ; \mathrm{v} / \mathrm{v} / \mathrm{v})$ at a flow of 3 $\mathrm{ml} / \mathrm{min}$. Peptidoleukotrienes $\left(\mathrm{LTC}_{4}\right.$ and $\left.\mathrm{LTD}_{4}\right)$ eluted in the $\mathrm{MeOH}$ fractions from Sep-Pak cartridge extractions were resolved with a Beckman Ultrasphere-ODS column eluted with $\mathrm{MeOH} /$ $\mathrm{H}_{2} \mathrm{O} /$ acetic acid (65:35:0.01; v/v/v), $\mathrm{pH} 5.7$, at 1 $\mathrm{ml} / \mathrm{min}$. Incubations of PMN with 15R-HETE were stopped with $\mathrm{MeOH}$ and methyl formate fractions of the Sep-Pak $\mathrm{C}_{18}$ extracted products were injected into an Altex Ultrasphere ODS column $(5 \mu \mathrm{m}, 10 \mathrm{~mm} \times 25 \mathrm{~cm})$ eluted with $\mathrm{MeOH} / \mathrm{H}_{2} \mathrm{O} /$ acetic acid (65:35:0.01; v/v/v) using a flow of $3 \mathrm{ml} / \mathrm{min}$. The material beneath peaks absorbing at $300 \mathrm{~nm}$ were individually collected after RP-HPLC and analyzed by gas chromatography-mass spectrometry (GC-MS) employing a Hewlett-Packard 5890 GC series II equipped with a 5971 A mass-selective quadrapole detector as in Clària and Serhan (4).

\section{Reverse Transcription and PCR}

Total RNA was obtained from A549 cells by the guanidinium isothiocyanate-cesium chloride method and cDNA was produced by reverse transcription (RT). Oligonucleotide primers were constructed from published sequences of PGHS-1 and PGHS-2 (5'-TGC CCA GCT CCT GGC CCG CCG CTT-3' [sense] and 5'-GTG CAT CAA CAC AGG CGC CTC TTC-3' [antisense], and 5'-TTC AAA TGA GAT TGT GGG AAA ATT GCT-3' [sense] and 5' -AGA TCA TCT CTG CCT GAG TAT CTT-3' [antisense], respectively) (12); of 15-LO (5'-ATG GGT CTC TAC CGC ATC CGC GTG TCC ACT-3' [sense] and 5' -CAC CCA GCG GTA ACA AGG GAA CCT GAC CTC-3' [antisense] (13); of 12-LO (5'-AGT TCC TCA ATG GTG CCA AC-3' [sense] and 5'-ACA GTG TTG GGG TTG GAG AG-3' [antisense]) (14); and of 5-LO (5'-GAA GAC CTG ATG TTT GGC TACC-3' [sense] and 5'-AGG GTT CTC ATC TCC CGG-3' [antisense]) (15). Amplification of the glyceraldehyde-3phosphate dehydrogenase (GAPDH) primers was performed with 5'-CCA CCC ATG GCA AAT TCC ATG GCA-3' (sense) and 5' -TCT AGA CGG CAG GTC AGG TCC ACC-3' (antisense). PGHS-1, PGHS-2, and GAPDH samples were amplified for
25 cycles of denaturation at $94^{\circ} \mathrm{C}$ for $1 \mathrm{~min}$, annealing at $58^{\circ} \mathrm{C}$ for $2 \mathrm{~min}$ and extension at $72^{\circ} \mathrm{C}$ for $3 \mathrm{~min}$. 5-, 12-, and 15-LO were amplified at $94^{\circ} \mathrm{C}(1 \mathrm{~min}), 55^{\circ} \mathrm{C}(2 \mathrm{~min})$, and $72^{\circ} \mathrm{C}(2.5$ min) for 35 cycles. PCR products were analyzed by electrophoresis in $2 \%$ agarose gel and their identity was monitored by restriction enzyme analysis. For detection of specific PCR-amplified targets, $0.5 \mu \mathrm{Ci}$ of $\left[{ }^{32} \mathrm{P}\right] \mathrm{dCTP}(3000 \mathrm{Ci} / \mathrm{mmol})$ was added to the PCR mixture and the products were quantified by phosphorimager using Image-Quant programming (Molecular Dynamics, San Lorenzo, CA, U.S.A.).

\section{Cell Proliferation}

A microculture 3,(4,5-dimethylthiazoyl-2-yl) 2,5(diphenyl-tetrazolium bromide) (MTT) assay (16) was used to examine the actions of LXs and other eicosanoids on cell proliferation. A549 cells and fibroblasts from exponential-phase maintenance cultures were counted and dispensed within replicate $96-$ well culture plates in $100-\mu l$ volumes of medium ( $\sim 2000$ cells/well). Following $24 \mathrm{hr}$ at $37^{\circ} \mathrm{C}$, the culture medium was removed, and fresh medium $(100 \mu \mathrm{l})$ containing either the compounds (5-1000 $\mathrm{nM}$ ) or vehicle (medium plus $0.15 \%$ ethanol) was added to four replicates for each condition studied and the culture plates were then incubated for up to $96 \mathrm{hr}$ at $37^{\circ} \mathrm{C}$ in a $5 \% \mathrm{CO}_{2}$ atmosphere. At the end of this period, $25 \mu \mathrm{l}$ of freshly prepared MTT in HBSS ( 5 $\mathrm{mg} / \mathrm{ml}$ ) was added to the wells and the plates were incubated for $4 \mathrm{hr}$ at $37^{\circ} \mathrm{C}$. Dye solution was aspirated, wells were washed once with HBSS and dye taken up by the cells was extracted in $100 \mu \mathrm{l}$ of isopropyl alcohol: $1 \mathrm{~N} \mathrm{HCl}$ $(96: 4, v / v)$ and quantitated at $570 \mathrm{~nm}$ using a microplate reader (Molecular Devices, Menlo Park, CA, U.S.A.). In some experiments, cells were grown in 12-well culture plates, treated as above and enumerated using a Neubauer hemocytometer. Viability was assessed routinely using trypan blue exclusion assay. For the A549 cells and fibroblasts, a linear relation was established for the MTT values and cell number within the range of the experiments shown $(r=0.995 ; p<$ $0.005)$. A549 cells grown for $72 \mathrm{hr}$ in the presence of the compounds (5-1000 $\mathrm{nM}$ ) or vehicle $(0.15 \%$ EtOH) were lysed with $0.25 \mathrm{~N} \mathrm{NaOH}$ and the cellular protein content was determined by applying the Bio-Rad (Richmond, CA, U.S.A.) microassay method using bovine serum albumin as standard. The mean cellular protein content in resting A549 cells was $46.6 \pm 1.5 \mathrm{pg} / \mathrm{cell}$. 


\section{Thymidine Incorporation and DNA Synthesis}

A549 cells $\left(\sim 2 \times 10^{4}\right.$ cells $\left./ \mathrm{ml}\right)$ were seeded in 96-well plates, allowed to settle for $24 \mathrm{hr}$ and grown for an additional $72 \mathrm{hr}$ in the presence of compounds (5-1000 nM) or vehicle (medium plus $0.15 \%$ ethanol). Twenty-four hours before the assay, $2 \mu \mathrm{Ci} / \mathrm{ml}$ of methyl- $\left[{ }^{3} \mathrm{H}\right]$-thymidine (specific activity $6.7 \mathrm{Ci} / \mathrm{mmol}$ ) were added to each well (17). After pulse-labeling, each well was washed four times with cold $\mathrm{DPBS}^{2+}$, and the cells were lysed with $\mathrm{NaOH}(0.25 \mathrm{~N})$ and radioactivity measured.

The Student's $t$ test was used for statistical analysis, and differences were considered significant at a $p$ value of $\leq 0.05$.

\section{RESULTS}

Eicosanoids are formed by initial oxygenation of arachidonic acid by PGHS or LO enzymatic pathways (2). To assess which of the eicosanoid- generating enzymes are present and/or regulated by cytokines in A459 cells, mRNA levels of PGHS-1 and -2, and 5-, 12-, and 15-LO from A549 cells grown in the presence or absence of IL- $1 \beta$ were monitored by RT-PCR followed by phosphorimager analysis. As illustrated in Fig. 1 , mRNA levels for PGHS-2 were significantly increased ( $\sim 2$-fold) after stimulation of A549 cells with IL- $1 \beta$. In contrast, mRNA levels for PGHS- 1 and 5-LO were not significantly altered after exposure of the cells to cytokine (Fig. 1). A549 cells failed to show either 15- or 12-LO expression before or after cytokine induction (Fig. 1). The absence of 15-LO mRNA in A549 cells was further confirmed by performing the RT-PCR in parallel with human lung tissue and peripheral blood monocyte RNA, which are known positive and negative sources of 15-LO mRNA (14), respectively (Fig. 1, inset).

To characterize the profile of monohydroxy products produced by airway epithelial cells, IL$1 \beta$-stimulated A549 cells $\left(1.5 \times 10^{6}\right.$ cells $\left./ \mathrm{ml}\right)$
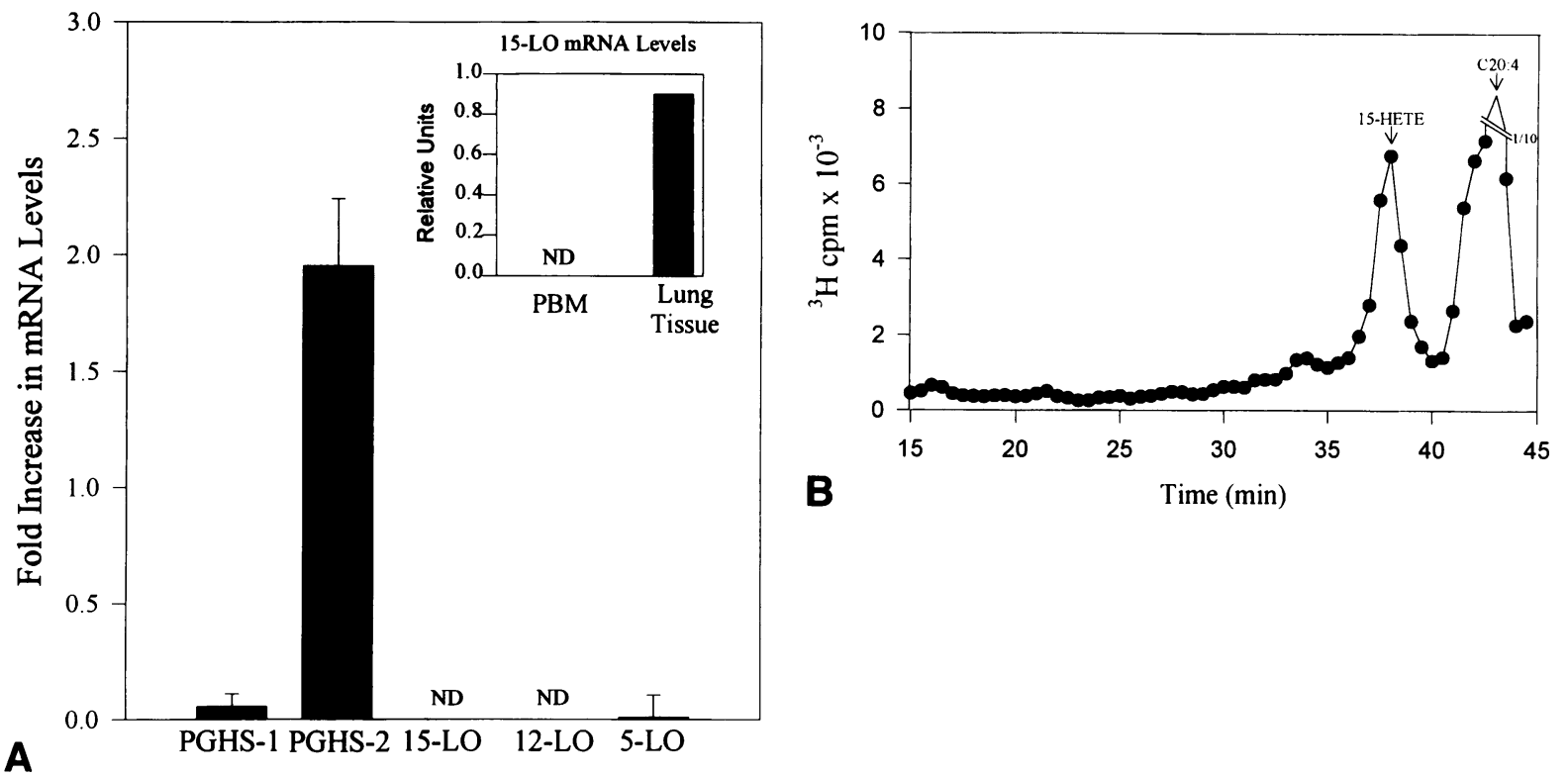

FIG. 1. PGHS and LO expression and monohydroxy products analysis in A549 cells

(A) PGHS and LO expression in A549 cells. Cells were grown for $24 \mathrm{hr}$ at $37^{\circ} \mathrm{C}$ in $\mathrm{T}-75 \mathrm{~cm}^{2}$ flasks in the presence or absence of IL- $1 \beta(1 \mathrm{ng} / \mathrm{ml})$. Extracted total RNA $(1 \mu \mathrm{g})$ was taken for RT and PCR using specific oligonucleotides for PGHS-1 and -2, 15-, 12-, and 5-LO, and GAPDH. Radioactive bands were quantified directly by phosphorimager analysis, normalized to the expression of GAPDH, and expressed as fold increase in mRNA levels after exposure to IL-1 $\beta$. Inset: 15-LO mRNA expression in human lung tissue and peripheral blood monocytes (PBM). ND, not detected. (B) RP-HPLC profile of $\left[{ }^{3} \mathrm{H}\right]$-labeled mono-HETEs from permeabilized IL- $1 \beta$-treated A549 cells $\left(1.5 \times 10^{6}\right.$ cells $\left./ \mathrm{ml}\right)$ and exposed to $\left[{ }^{3} \mathrm{H}\right]$-arachidonic acid $(0.25 \mu \mathrm{Ci} / \mathrm{ml})$ plus unlabeled arachidonic acid $(20 \mu \mathrm{M})$ for $20 \mathrm{~min}$ at $37^{\circ} \mathrm{C}$. Products were extracted and chromatographed using a linear gradient of methanol: $\mathrm{H}_{2} \mathrm{O}: a c e t i c$ acid $(65: 35: 0.01 ; \mathrm{v} / \mathrm{v} / \mathrm{v})$ and methanol:acetic acid $(99.99: 0.01, \mathrm{v} / \mathrm{v})$ at a flow rate of $1.0 \mathrm{ml} / \mathrm{min}$. Arrows denote co-chromatography of synthetic standards. 
were permeabilized and incubated with arachidonic acid, and the products formed were extracted and analyzed by RP-HPLC. The chromatographic profile revealed the presence of a major product with strong UV absorbance at 234 nm which coeluted with synthetic 15-HETE (data not shown). Also, when $\left[{ }^{3} \mathrm{H}\right]$-arachidonic acid was added to IL- $1 \beta$-treated A549 cells, radiolabeled material was recovered beneath the peak coeluting with 15-HETE (Fig. 1B). In these experiments, we did not consistently observe the formation of either 5- or 12-HETE. While ASA treatment of A549 cells led to a marked increase in the formation of 15-HETE, incubation of permeabilized A549 cells with 17-ODYA, a reported inhibitor of P450 eicosanoid metabolism (10), resulted in $\sim 50 \%$ reduction in 15-HETE (Fig. 2A). 17-ODYA is a potent inhibitor of P450 eicosanoid metabolism and does not selectively inhibit either cyclooxygenase or lipoxygenase activity (see Muerhoff et al. [10] and supplier's supporting materials). The 5-LO inhibitor (Rev5901 isomer) did not alter the amount of 15HETE produced by A549 cells in a statistically significant fashion. Heat-denatured A549 cells reduced the quantities of 15-HETE by $\sim 90 \%$, suggesting that an enzymatic component is involved in its formation. Intact A549 cells treated with IL-1 $\beta$ (1 ng/ml) for $24 \mathrm{hr}$ also produced 15-HETE from endogenous sources of arachidonate $\left(25.0 \pm 10.0 \mathrm{ng} / 10^{7}\right.$ cells $)$. Taken together these results indicate that 15-HETE is the main monohydroxy product generated by A549 cells and suggest that both acetylated PGHS-2 and cytochrome $\mathrm{P} 450$ contribute to its biosynthesis.

To investigate the time course for generation of 15-HETE from endogenous sources of arachidonate, intact A549 cells were exposed to IL- $1 \beta$ ( 1 $\mathrm{ng} / \mathrm{ml}$ ) for up to $48 \mathrm{hr}$ and the amount of immunoreactive 15-HETE present in the cell supernatant was monitored using a specific RIA. In resting conditions, A549 cells produced significant levels of immunoreactive 15-HETE (19.1 \pm $10.5 \mathrm{ng} / 10^{7}$ cells; $n=3 ; d=2$ ). These values were not changed by addition of ionophore $\mathrm{A}_{23187}(5 \mu \mathrm{M})$ in the absence of IL-1 $\beta$ (Fig. 2B). Also, in the absence of ionophore stimulation, addition of IL- $1 \beta$ to A549 cells for up to $48 \mathrm{hr}$ did

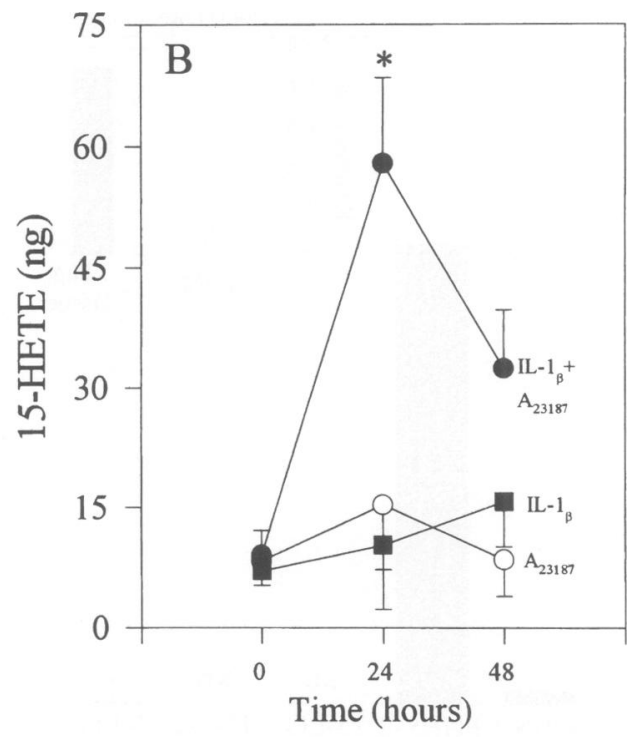

FIG. 2. 15-HETE generation

(A) A549 cells $\left(6 \times 10^{6}\right.$ cells/flask) were treated with $\mathrm{IL}-1 \beta(1 \mathrm{ng} / \mathrm{ml})$ for $24 \mathrm{hr}$, subjected to freeze-thaw (two cycles), exposed for $20 \mathrm{~min}$ to either vehicle $(0.1 \% \mathrm{v} / \mathrm{v}$ EtOH), ASA, the cytochrome P450 inhibitor (17-ODYA, 5 $\mu \mathrm{M})$ or the 5 -LO inhibitor (Rev-5901 isomer, $5 \mu \mathrm{M})$ and incubated with arachidonic acid $(20 \mu \mathrm{M})$ for $20 \mathrm{~min}$ at $37^{\circ} \mathrm{C}$. In some experiments, cells were heat-denatured $\left(100^{\circ} \mathrm{C}, 60 \mathrm{~min}\right)$ before incubation. Incubations were stopped with addition of methanol $(2 \mathrm{v})$, and products were extracted for RP-HPLC. Data are mean \pm SEM from four to six separate flasks. ${ }^{*} p<0.05$ and ${ }^{*} p<0.01$ for treatments versus control. (B) Time course of 15-HETE formation from endogenous sources. A549 cells $\left(1.5 \times 10^{6}\right.$ cells $\left./ \mathrm{ml}\right)$ were grown for $48 \mathrm{hr}$ in the absence or presence of IL- $1 \beta(1 \mathrm{ng} / \mathrm{ml})$ and incubated $\left(30 \mathrm{~min}\right.$ at $\left.37^{\circ} \mathrm{C}\right)$ in $4 \mathrm{ml}$ of $\mathrm{HBSS}$ with or without $\mathrm{A}_{23187}(5 \mu \mathrm{M})$. 15HETE levels were determined by RIA. Results represent the mean \pm SEM of three different experiments determined by duplicate. ${ }^{*} p<0.05$ for treatments versus vehicle. 
not result in an augmented generation of 15HETE (Fig. 2B). In sharp contrast, addition of IL- $1 \beta$ plus $A_{23187}$ stimulation of A549 cells led to a marked increase in the production of 15-HETE (Fig. 2B). Maximal 15-HETE levels were reached at $24 \mathrm{hr}$ of exposure to the cytokine and declined thereafter.

To determine the stereochemistry of the alcohol in 15-HETE produced by A549 cells, we examined the relative amounts of individual $R$ and $S$ enantiomers of 15 -HETE generated by IL$1 \beta$-treated A549 cells using a chiral phase HPLC analysis (see Materials and Methods). PGHS-2 and cytochrome P450 are two enzymes other than 15-LO that can convert arachidonic acid to 15-HETE. The carbon (C)-15 alcohol group of 15-HETE derived from ASA-acetylated PGHS-2 is mainly in the $R$ configuration (18). Here, 15HETE produced by IL- $1 \beta$-primed A549 cells was converted to its methyl ester and subjected to SP-HPLC chiral analysis. The 15-HETE from activated A549 cells was $65 \%$ in the $R$ and $35 \%$ in the $S$ configuration (Fig. 3). Pretreatment of A549 cells with ASA (for $20 \mathrm{~min}$ at $37^{\circ} \mathrm{C}$ ) resulted in a 3-fold increase in the amount of $15 R$ HETE, whereas formation of $15 S$-HETE was not altered (Fig. 3). In the presence of ASA, 15RHETE accounted for $85 \%$ of the total amount of 15-HETE produced by A549 cells. These results indicate that the majority of 15-HETE generated by IL-1 $\beta$-primed A549 cells in the presence of ASA was in the $R$ configuration.

Transcellular eicosanoid biosynthesis is an important means of amplifying lipid mediators as well as generating new mediators (7). Costimulation of human endothelial cells and PMN after ASA treatment results in the formation of a new class of bioactive eicosanoids (4). These novel eicosanoids were identified as 15-epi-LXs and their biosynthesis results from the transformation of ASA-triggered endothelial-derived $15 R$ HETE by leukocytes. In view of these findings, it is possible that formation of new eicosanoids by transcellular biosynthesis also occurs during epithelial cell-PMN interactions. To test this hypothesis, confluent A549 cells were exposed to IL- $1 \beta(1 \mathrm{ng} / \mathrm{ml}, 24 \mathrm{hr})$, treated with ASA and costimulated with PMN. Figure 4 (left panel) shows a representative HPLC profile of material obtained from stimulated cells exposed to ASA, which revealed the presence of four major products with strong UV absorbance when plotted at $300 \mathrm{~nm}$. On-line spectral analysis of these products showed that they each displayed a triplet of absorbing bands characteristic of conjugated tet-

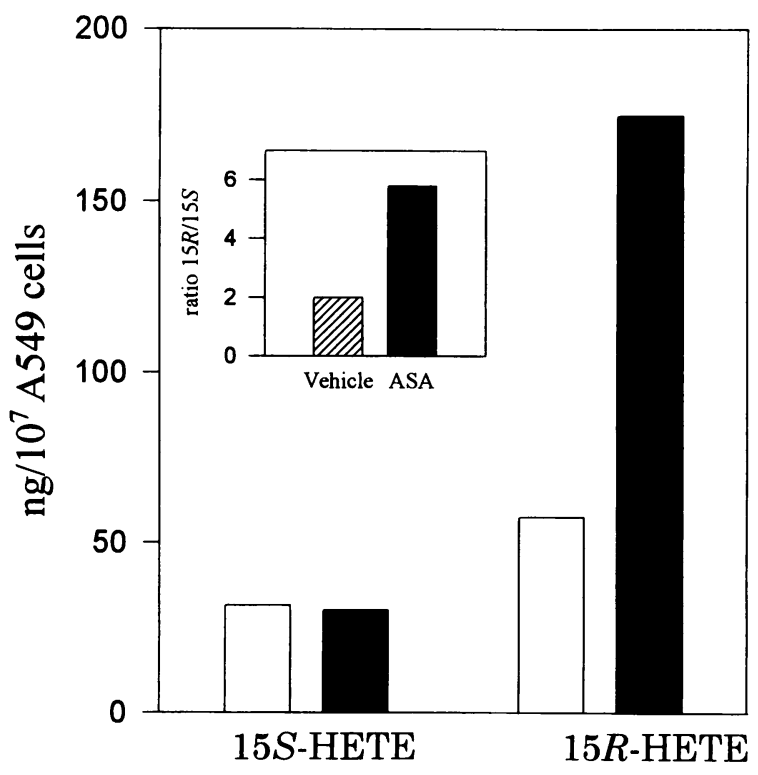

FIG. 3. Chirality of 15-HETE: ASA triggers 15RHETE formation

A549 cells $\left(10^{7}\right.$ cells/flask) were exposed to IL- $1 \beta$ ( 1 $\mathrm{ng} / \mathrm{ml})$ for $24 \mathrm{hr}$, treated with vehicle $(0.1 \% \mathrm{v} / \mathrm{v}$ ethanol) ( $\square$ ) or ASA $(\square)$ for 20 min and then incubated $\left(30 \mathrm{~min}, 37^{\circ} \mathrm{C}\right)$ in HBSS containing arachidonic acid $(20 \mu \mathrm{M})$ and $\mathrm{A}_{23187}(5 \mu \mathrm{M})$. Products were chromatographed by RP-HPLC (as in Fig. 1B) and the region containing 15-HETE was collected, extracted with chloroform and treated with diazomethane. Chiral analysis was performed with a Bakerbond DNBPG (see Materials and Methods for details). Results are representative of two separate experiments showing similar results. Inset: Ratio between A549-derived 15R- and 15S-HETE in the ab-

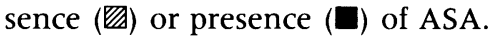

raene-containing chromophores indicative of the LX basic structure (maxima at $301 \mathrm{~nm}$ and shoulders at 288 and $316 \pm 2 \mathrm{~nm}$ ) (Fig. 4, right panels).

$\mathrm{LXA}_{4}$ and 15-epi-LXA 4 were identified in the chromatographic profiles on the basis of coelution with synthetic standards and the presence of the characteristic chromophore. In these co-incubations, 15 -epi-LXA $\mathrm{LAc}_{4}$ accounted for $\sim 88 \%$ of the total amount of $\mathrm{LXA}_{4}$ detected, which is in agreement with the observation that the majority of 15 -HETE generated by IL- $1 \beta$-primed A 549 cells exposed to ASA is predominantly in the $R$ configuration (Figs. 3 and 4). In this RP-HPLC system, 15-epi-11-trans-LXA 4 coeluted with $\mathrm{LXB}_{4}$, and 11-trans- $\mathrm{LXA}_{4}$ with 15-epi-LXB 4 (not shown). These LX isomers were not further resolved by HPLC and are denoted in the profile beneath peaks labeled A and B, respectively (Fig. 4, left panel). The compounds beneath 

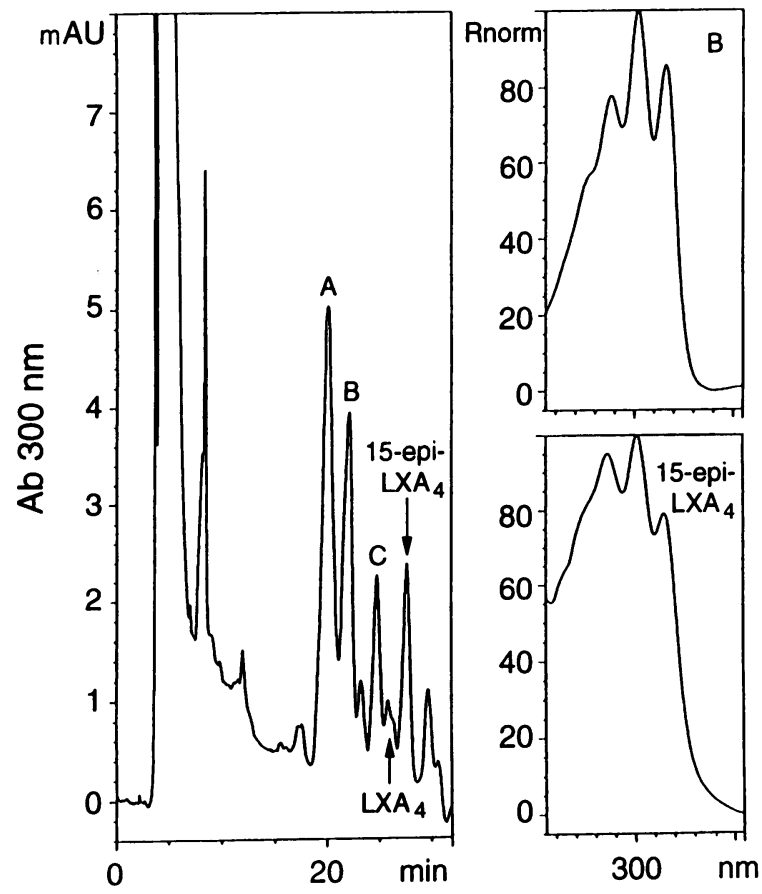

FIG. 4. Products from epithelial cell-PMN costimulation

RP-HPLC chromatogram (left panel) and on-line UV spectra (right panels). Confluent A549 cells were exposed to IL-1 $\beta$ ( $1 \mathrm{ng} / \mathrm{ml})$ for $24 \mathrm{hr}$, treated with ASA (20 min) and arachidonic acid $(20 \mu \mathrm{M}, 60 \mathrm{~s})$, and each incubated with freshly isolated PMN (A549 cell:PMN cell ratio of $1: 8$ ) followed by stimulation with ionophore $A_{23187}(5$ $\mu \mathrm{M})$ in $4 \mathrm{ml}$ of HBSS for $30 \mathrm{~min}$ at $37^{\circ} \mathrm{C}$. Products were extracted and taken to RP-HPLC as described in Materials and Methods. The chromatogram was plotted at $300 \mathrm{~nm}$ and is representative of $n=6$ experiments. Displayed spectra are from material eluting beneath Peak $B$ (identified as predominantly 15-epi- $\mathrm{LXB}_{4}$ ) and 15-epi-LXA (see text for details). Similar spectra, each showing absorbance consistent with tetraene chromophores, were obtained from $\mathrm{LXA}_{4}$ and Peaks A and $\mathrm{C}$.

Peaks A and B did resolve as OTMS, methyl ester derivatives in GC-MS (vide infra). The products were present in $\sim 8: 2$ ratio in favor of their $15 R$ epimers $(n=3)$. Compound C (Fig. 4, left panel) did not coelute with any of the previously identified LXs and was also present in the RP-HPLC profile from activated PMN incubated with $15 R$ HETE (data not shown, $n=5$ ). Material eluting beneath Compound $\mathrm{C}$ matched the physical properties of Compound III that we recently isolated from endothelial cell-PMN interactions (4). Although the complete stereochemistry of Compound $C$ remains to be determined, the UV spectral data and chromatographic mobilities suggest that it may be the 15-epimer form of 7-cis-11trans-LXA (19). Thus, the lipoxins generated during epithelial (A549 cell)-PMN costimulation after ASA treatment were predominantly 15-epiLX (Fig. 4).

In addition to the ability to produce LXs, co-incubations of activated PMN with A549 cells also generate significant amounts (approximately eight times more than tetraene-containing LXs) of peptidoleukotrienes (pLTs; $\mathrm{LTC}_{4}$ and $\mathrm{LTD}_{4}$ ) in the absence of ASA (Fig. 5). The amounts of both LXs and pLTs produced in these co-incubations were dependent upon individual cell ratios (Fig. $5 \mathrm{~A}$ and $\mathrm{B}$, insets). Exposure of airway epithelial A549 cells to ASA 20 min before adding PMN led to an increase in the formation of LXs and a decrease in pLTs (Fig. $5 \mathrm{~A}$ and B). Neither PMN nor A549 cells incubated separately in the absence or presence of ASA generated detectable levels of LXs or pLTs (Fig. 5 and data not shown). Taken together, these results indicate that, during A549 cell-PMN interactions, both LXs and pLTs originate from transcellular routes.

LXs are vasodilators and potent regulators of leukocyte responses, such as inhibition of chemotaxis, adhesion to endothelial cells, and transmigration across epithelium (reviewed in Ref. 3). In contrast, pLTs possess both vasoconstrictor and proinflammatory actions as well as stimulate the growth of several cell types including fibroblasts, smooth muscle cells, and glomerular epithelial cells (20). LXs reverse the vasoconstrictor action of $\mathrm{LTD}_{4}$ in rat renal hemodynamics and block LTC $_{4}$-stimulated hematopoiesis (reviewed in Ref. 3). Since ASA enhances 15-epi-LX formation and inhibits pLT biosynthesis (Fig. 5), these eicosanoids may play counterregulatory actions on cell proliferation and contribute to ASA's protective mechanisms in human cancer. To this end, we tested the effect of these LO products on epithelial cell proliferation (Fig. 6) and compared their actions with that of dexamethasone, a wellestablished inhibitor, employing a soluble microculture tetrazolium (MTT) assay (21). These experiments were performed with synthetic $\mathrm{LXA}_{4}$ and $\mathrm{LXB}_{4}$, which were available in sufficient quantities for bioassay, rather than the 15-epiLX, which are the major LX produced by these cells. As shown in Fig. 6, $\mathrm{LXA}_{4}$ and $\mathrm{LXB}_{4}$ inhibited A549 cell proliferation in a time- (Fig. 6A) and dose-dependent (Fig. 6B) fashion. $\mathrm{LXA}_{4}$ and $\mathrm{LXB}_{4}$ as well as dexamethasone $(1 \mu \mathrm{M})$ inhibited A549 cell proliferation after 72 and $96 \mathrm{hr}$ of treatment (Fig. 6A). After $72 \mathrm{hr}, \mathrm{LXA}_{4}$ shared the 

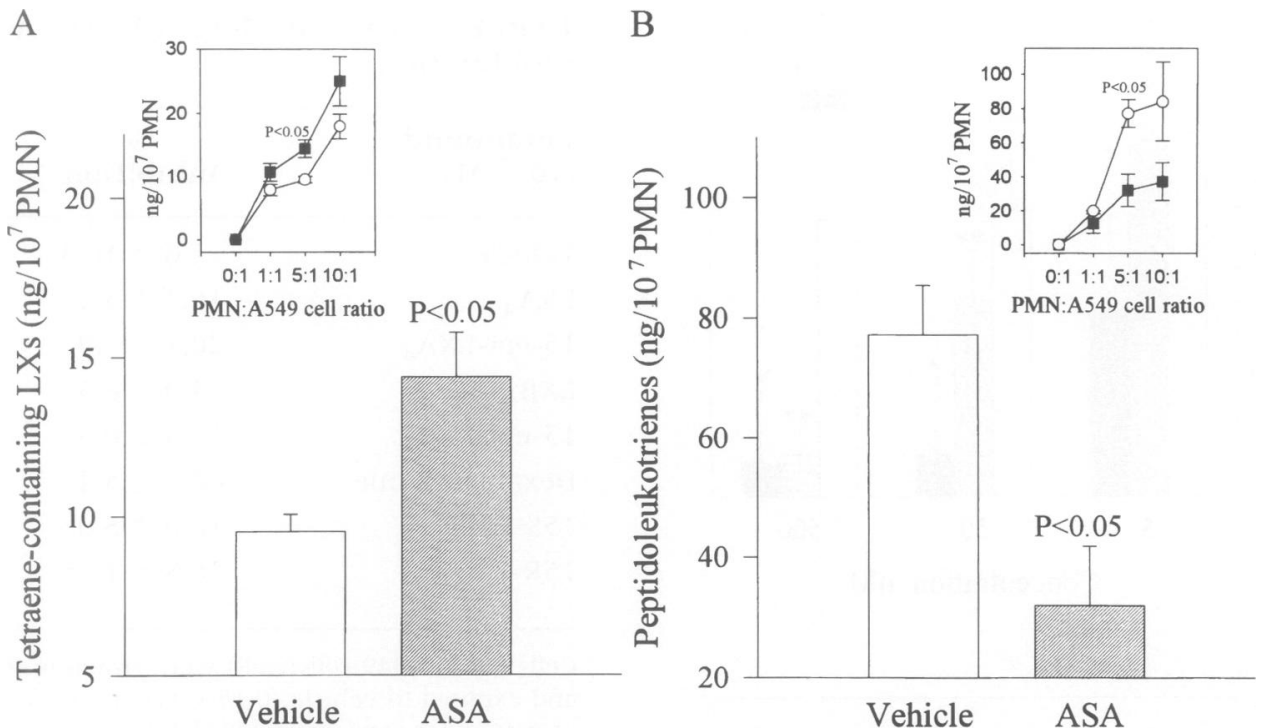

FIG. 5. ASA modulates both $\mathrm{LX}(\mathrm{A})$ and $\mathrm{pLT}(\mathrm{B})$ formation during epithelial cell-PMN costimulation A549 cells were exposed to IL- $1 \beta(1 \mathrm{ng} / \mathrm{ml}, 24 \mathrm{hr})$ and treated $\left(20 \mathrm{~min}, 37^{\circ} \mathrm{C}\right)$ with either vehicle $(0.1 \% \mathrm{v} / \mathrm{v})$ or ASA, before the addition of arachidonic acid $(20 \mu \mathrm{M}, 1 \mathrm{~min})$ and freshly isolated PMN (A549/PMN cell ratio of 1:5). Costimulations were carried out as in Fig. 4. Results represent the mean \pm SEM from three to five separate donors. Insets: Effect of cell ratio on generation of tetraene-containing LXs (LX plus 15-epi-LX) (A) and pLTs $\left(\mathrm{LTC}_{4}\right.$ plus $\left.\mathrm{LTD}_{4}\right)(\mathrm{B})$ during co-incubations of A549 cells with PMN in the absence (O) or presence ( $\square$ ) of ASA.

antiproliferative properties (Fig. 6) observed for dexamethasone with these cells (22). The halfmaximum inhibition $\left(\mathrm{IC}_{50}\right)$ for $\mathrm{LXA}_{4}$ was $\sim 80$ $\mathrm{nM}$ and that for dexamethasone was $\sim 7 \mathrm{nM}$. $\mathrm{LXB}_{4}$ at concentrations of 0.5 and $1 \mu \mathrm{M}$ was approximately three times more active than either $\mathrm{LXA}_{4}$ or dexamethasone (Fig. 6B). Interestingly, both $\mathrm{LXA}_{4}$ and $\mathrm{LXB}_{4}$ showed essentially equal potency for blocking A549 cell growth when each was added repeatedly to the cells (at 24-hr intervals) for three consecutive days (data not shown; $n=3 ; d=4$ ), suggesting that LX may be inactivated by these epithelial cells. Results from additional experiments employing direct cell enumeration (Fig. 7B) and measurement of total cellular protein content (data not shown;
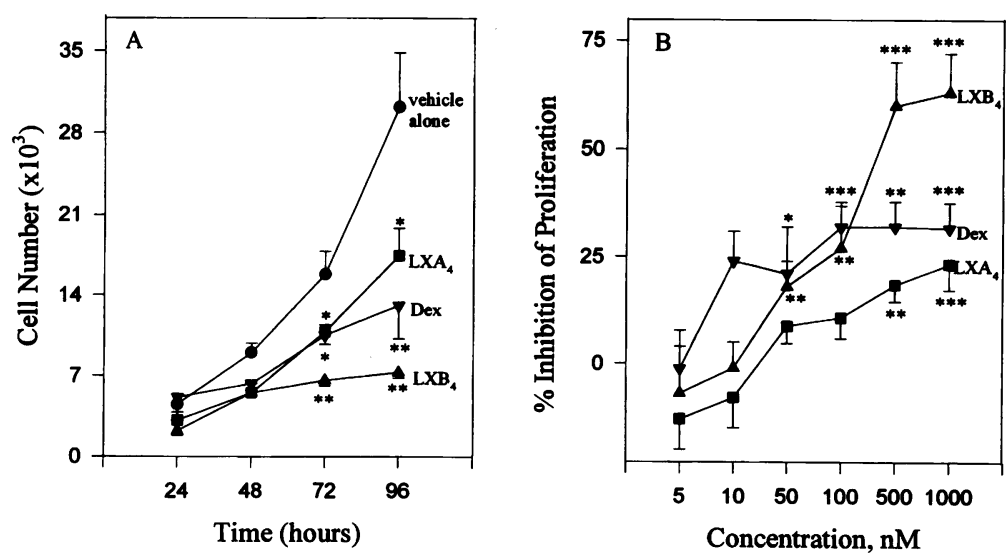

FIG. 6. LX inhibits A549 cell proliferation

(A) Time-dependent growth arrest. A549 cells in 96-well plates were treated with either vehicle $(0.15 \% \mathrm{EtOH})$ or equimolar concentrations $\left(10^{-6} \mathrm{M}\right)$ of $\mathrm{LXA}_{4}$, $\mathrm{LXB}_{4}$, or Dex for up to $96 \mathrm{hr}$ at $37^{\circ} \mathrm{C}$. At the indicated intervals, cells were harvested for the MTT assay. Data are mean \pm SEM of three to seven experiments performed in quadruplicate. ${ }^{*} p<0.05$ and ${ }^{* *} p<0.005$ for compounds versus vehicle. (B) Concentration dependence. A549 cells were exposed to $\mathrm{LXA}_{4}, \mathrm{LXB}_{4}$, or Dex at the indicated concentrations for $72 \mathrm{hr}$ at $37^{\circ} \mathrm{C}$. Results are mean \pm SEM of five to eight experiments performed in quadruplicate. Results are expressed as the percent inhibition of proliferation relative to vehicle. ${ }^{\star} p<0.05$, ${ }^{* *} p<0.025$, and ${ }^{* * *} p<0.005$ for compounds versus vehicle. 
A)

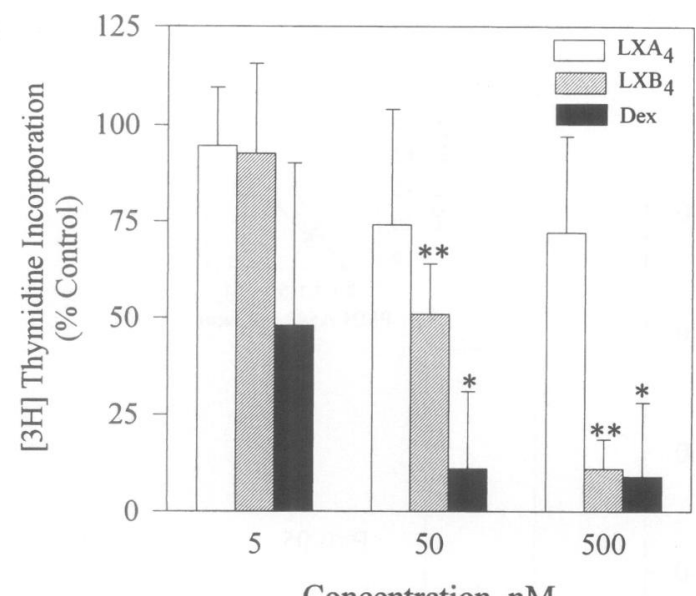

B)

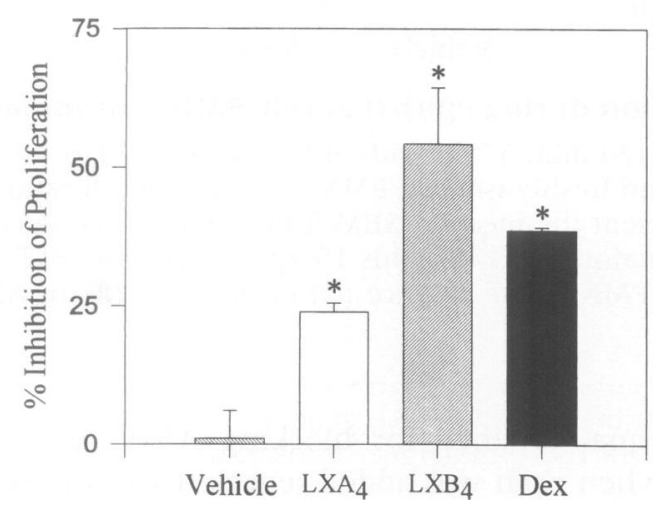

FIG. 7. Lipoxin inhibits cell proliferation

(A) DNA synthesis. A549 cells were grown for $72 \mathrm{hr}$ in the presence of test compounds (5-500 nM). Twenty-four hours before the assay, methyl- $\left[{ }^{3} \mathrm{H}\right]-$ thymidine $(2 \mu \mathrm{Ci} / \mathrm{ml})$ was added to each well. Cells were subsequently washed four times with DPBS ${ }^{2+}$ $\left(4^{\circ} \mathrm{C}\right)$, lysed with $0.25 \mathrm{~N} \mathrm{NaOH}$, and radioactivity incorporation was monitored. Values represent mean \pm SEM of three different experiments performed in quadruplicate. Results are expressed as the percentage of $\left[{ }^{3} \mathrm{H}\right]$-thymidine incorporation relative to vehicle alone. ${ }^{*} p<0.05$ and ${ }^{*} p<0.005$ for compounds versus vehicle. (B) Direct cell count. A549 cells were seeded in 12-well culture plates in the presence of compounds $(1 \mu \mathrm{M})$ and cell counts were obtained at $72 \mathrm{hr}$ by enumerating the trypanblue excluding cells. Values represent mean \pm SEM of three different experiments. Results are expressed as the percentage inhibition of proliferation relative to buffer. ${ }^{*} p<0.05$ for compounds versus vehicle.

$n=3 ; d=4$ ) paralleled those obtained with MTT assay, thus confirming the anti-proliferative actions of LXs in A549 cells. Furthermore, DNA synthesis was blocked, as determined by $\left[{ }^{3} \mathrm{H}\right]-$ thymidine incorporation, when A549 cells were exposed for $72 \mathrm{hr}$ to concentrations of $50 \mathrm{nM}$ or
TABLE 1. LX and 15-epi-LX actions on cell proliferation

\begin{tabular}{lcc}
\hline $\begin{array}{l}\text { Compound } \\
\left(\mathbf{1 0}^{-7} \mathbf{M}\right)\end{array}$ & $\begin{array}{c}\% \\
\text { Inhibition }\end{array}$ & $\begin{array}{c}\boldsymbol{p} \\
\text { Value }^{a}\end{array}$ \\
\hline Vehicle & $1.6 \pm 10.3$ & NS \\
LXA $_{4}$ & $16.3 \pm 5.2$ & NS \\
15 -epi-LXA & $20.1 \pm 1.9$ & $<0.025$ \\
LXB $_{4}$ & $34.0 \pm 8.5$ & $<0.005$ \\
15-epi-LXB & $79.3 \pm 0.3$ & $<0.001^{b}$ \\
Dexamethasone & $42.1 \pm 5.4$ & $<0.005$ \\
15S-HETE & $10.0 \pm 8.0$ & NS \\
15R-HETE & $16.8 \pm 11.5$ & NS \\
\end{tabular}

Cells (2000 A549 cells/well) were grown in 96-well plates and exposed to vehicle $(0.15 \% \mathrm{v} / \mathrm{v}$ in EtOH/F-12K media) or equimolar concentrations $\left(10^{-7} \mathrm{M}\right)$ of $\mathrm{LXA}_{4}, 15$-epi$\mathrm{LXA}_{4}, \mathrm{LXB}_{4}, 15-e \mathrm{ep}-\mathrm{LXB}_{4}$, or dexamethasone for $72 \mathrm{hr}$ at $37^{\circ} \mathrm{C}$. Values represent mean $\pm S E M$ from three to seven experiments performed in quadruplicate and are expressed as percentage inhibition of cell growth.

${ }^{a} p$ values denote statistical differences compared with cells alone.

${ }^{b} p<0.001$ for 15-epi- $\mathrm{LXB}_{4}$ compared with $\mathrm{LXB}_{4}$.

higher of $\mathrm{LXB}_{4}$ or dexamethasone (Fig. 7A). After incubation of A549 cells with these compounds, cells were $\sim 98 \%$ viable, as determined by trypan blue exclusion assay, indicating that these compounds were not cytotoxic within the range of concentrations used in these experiments.

The 15-hydroxy epimeric forms of $\mathrm{LXA}_{4}$ and $\mathrm{LXB}_{4}$ (15-epi-LXA 4 and 15-epi-LXB ${ }_{4}$, respectively), which were the dominant forms of LX isolated from these cells, proved to also be potent inhibitors of epithelial cell proliferation (Table 1 ). At equimolar levels (100 nM), 15-epi-LXA 4 inhibited A549 cell growth to a similar extent as $\mathrm{LXA}_{4}$. On the other hand, 15-epi-LXB ${ }_{4}$ isolated from conversion of $15 R$-HETE by activated PMN and added back to the A549 cells gave a more potent antiproliferative activity than $\mathrm{LXB}_{\mathbf{4}}(\sim 80$ versus $\sim 34 \%$ inhibition of proliferation, $p<$ 0.001 ; Table 1). This compound was characterized by UV, HPLC, and GC-MS ( $C$ value: 23.3 ). Diagnostic ions for the OTMS methyl ester were $\mathrm{m} / \mathrm{z} 173$ (base peak), 203, 289, 379, and less prominent ions at $482\left(\mathrm{M}^{+}-100\right)$ (It was not possible to obtain its molecular ion because of the low abundance of this ion). Thus, the predominant material beneath the peak labeled $B$ in 
Fig. 4 was consistent with that of 15 -epi- $\mathrm{LXB}_{4}$ which gave a shorter $C$ value and separated from $\mathrm{LXB}_{4}$ as OTMS, methyl ester derivative in GC-MS analysis. The mass spectra of 15-epi$\mathrm{LXB}_{4}$ and $\mathrm{LXB}_{4}$ were essentially identical (not shown) but their $C$ values were distinct. Material eluting beneath the peak denoted $C$ (isolated from activated PMN incubated with $15 R$-HETE) also showed a mild inhibitory action on epithelial cell growth ( $18 \pm 2 \%$ inhibition of proliferation; $n=3 ; d=4)$. In sharp contrast, 15-epi-trans$\mathrm{LXA}_{4}$, 11 -trans- $\mathrm{LXB}_{4}, 8,9$-acetylenic-LXB ${ }_{4}$, peptidoleukotrienes $\left(\mathrm{LTC}_{4}\right.$ and $\left.\mathrm{LTD}_{4}\right)$, and the $\mathrm{LX}$ precursors (15S- and 15R-HETE) each tested at $10^{-6}-10^{-9} \mathrm{M}$ were not able to inhibit significantly A549 cell proliferation (data not shown; $n=3-5 ; d=4)$. These results indicate that LX and 15-epi-LX gave a stereoselective action in blocking cell proliferation in A549 cells. We also tested $\mathrm{LXA}_{4}$ and $\mathrm{LXB}_{4}$ with human skin fibroblasts to determine if they were antiproliferative for this cell type. At $100 \mathrm{nM}$, both $\mathrm{LXA}_{4}$ and $\mathrm{LXB}_{4}$ inhibited proliferation of fibroblasts. $\mathrm{LXB}_{4}$ gave $38.0 \pm 7.5 \%$ inhibition and $\mathrm{LXA}_{4} 10.7 \pm$ $1.8 \%$ compared with dexamethasone $(29.7 \pm$ $0.4 \%)$ as positive control $(n=3)$.

\section{DISCUSSION}

The results of the present study demonstrate that ASA triggers the formation of 15-epi-LXs (ATL) during costimulation of the human adenocarcinoma A549 cell line (epithelial cells) and PMN. Their formation involves transcellular biosynthetic mechanisms that are similar to those described recently for human endothelial cell-PMN interactions (4). These novel eicosanoids were generated by PMN that transform ASA-triggered epithelial-derived 15R-HETE (Figs. 1-4). Although several routes of 15-HETE biosynthesis were potentially operative in the A549 cells, the observation that these cells do not possess 15-LO activity (if present, 15-LO would have generated predominantly $15 S$-HETE) points to the involvement of PGHS or other enzymes in its generation. This possibility is supported by the observation that IL-1 $\beta$-primed A549 cells show an increased PGHS-2 expression (Fig. 1) and that formation of 15-HETE is enhanced following either ASA or IL- $1 \beta$ treatment (Fig. 2). Also, chiral analysis of the A549-derived 15-HETE formed in the presence of ASA indicated that its C-15 alcohol was predominantly in the $R$ configuration (Fig. 3). These results are consistent with find-

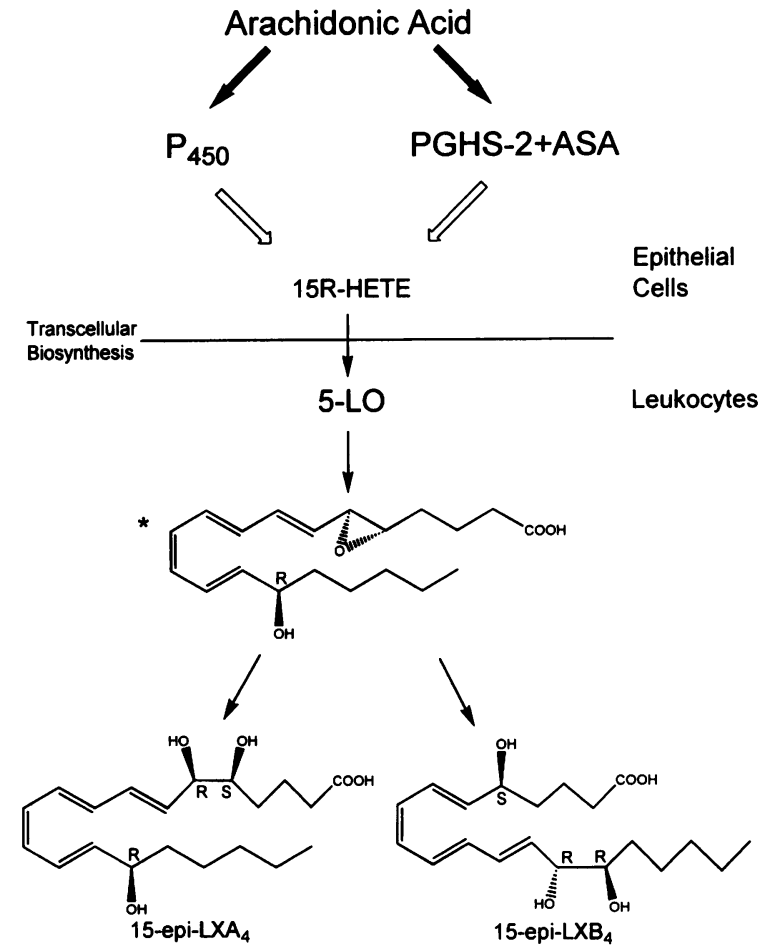

FIG. 8. Proposed scheme for generating 15epi-LXs

ASA-acetylated PGHS-2 and/or P450 activities contribute to 15R-HETE generation. Epithelial-derived $15 R$-HETE undergoes transcellular conversion by leukocyte 5-LO to a 15-epi-5(6)-epoxytetraene intermediate, which is common to both 15-epi-LXA 4 and 15-epi-LXB $\mathrm{L}_{4}$. The complete stereochemistry of 15epi- $\mathrm{LXA}_{4}$ has been determined (4), and the stereochemical assignment of 15 -epi- $\mathrm{LXB}_{4}$ is tentative.

ings from both human recombinant PGHS-2 and tracheal epithelial cells where ASA acetylates PGHS- 2 and modifies its catalytic properties resulting in conversion of arachidonic acid to $15 R$ HETE and inhibition of PG biosynthesis (Ref. 18 and for review see Ref. 23).

Cytochrome P450-dependent oxygenation of arachidonic acid also results in the stereoselective formation $(40 \% R$ and $60 \% S$ configuration) of 15-HETE (24). The presence of an active cytochrome P450 enzyme system in human airway A549 cells (25) together with the results that inhibition of $\mathrm{P} 450$ as well as heat denaturing blocks 15-HETE generation in these cells (Fig. 2A) suggests that this enzyme system in epithelial cells also contributes to 15-HETE biosynthesis and the generation of 15-epi-LX by transcellular routes (Fig. 8). Taken together, these observations (Figs. 1-4) establish the existence of two separate enzymatic pathways (i.e., 
ASA-acetylated PGHS-2 and cytochrome P450), which can initiate the formation of 15-epi-LX during airway epithelial cell-PMN interactions (Fig. 8). Also, it should be noted that, in view of ASA's ability to induce P450 enzymes (26), it is possible that these two independent routes may act in concert to generate 15-epi-LX.

Evidence is presented for the formation of both 15 -epi-LXA ${ }_{4}$ and 15 -epi-LXB ${ }_{4}$ by epithelial cell-PMN interactions (Fig. 4), observations that extend our recent demonstration of 15-epi-LXA generation by endothelial-PMN interactions (4). The levels of $15 R$-HETE produced by epithelial cells were higher than those generated by ASAtreated endothelial cells, which permitted us to consistently identify the $\mathrm{LXB}_{4}$-like product (i.e., $\mathrm{m} / \mathrm{z} 173$ base peak in GC-MS) from $15 R$-HETE, vide infra. The transcellular route of 15 -epi-LX biosynthesis is likely to proceed via a 15-epi5(6)epoxytetraene intermediate (i.e., 15(R)-epoxytetraene) produced by leukocyte 5-LO conversion of epithelial-derived 15R-HETE. This intermediate would be attacked by putative epoxide hydrolases at either $\mathrm{C} 6$ to give 15-epi$\mathrm{LXA}_{4}$ or $\mathrm{C} 14$ to give 15 -epi-LXB 4 (Fig. 8) (which is analogous to the mechanisms proposed for the biosynthesis of LX from $15 S$ oxygenating routes (for review see Ref. 3). By analogy with the physical properties of $\mathrm{LXA}_{4}$ and $\mathrm{LXB}_{4}$ 15-epi$\mathrm{LXA}_{4}$ and 15-epi-LXB 4 are also susceptible to isomerization to give their corresponding alltrans isomers (i.e., 15-epi-11-trans- $\mathrm{LXA}_{4}$ and 15epi-8-trans- $\mathrm{LXB}_{4}$ ) (Fig. 4). The chromatographic behavior (Fig. 4, Compound $\mathrm{B}$ ) and diagnostic ions were consistent with the 15 -epi- $\mathrm{LXB}_{4}$ structure, yet it should be noted that this assignment of complete stereochemistry of the double bond geometry for 15-epi-LXB ${ }_{4}$ is tentative (Fig. 8). The 15-epi-5(6)epoxytetraene is also the likely intermediate for enzymatic production of Compound $C$, which is consistent with the proposed structure of 15-epi-7-cis-11-trans-LXA 4 (Fig. 4).

In addition to 15-epi-LXs, incubation of A549 cells together with activated PMN led to formation of pLTs by transcellular routes. Their biosynthesis is likely to involve the export of the epoxide $\mathrm{LTA}_{4}$ from PMN and its further transformation to $\mathrm{LTC}_{4}$ and $\mathrm{LTD}_{4}$ in epithelial cells. Interestingly, ASA inhibited the formation of pLT by co-incubations of epithelial cells and PMN (Fig. 5). This observation is consistent with and may explain at the cellular level the reduction of pLT release from gastric mucosa observed during the oral administration of ASA to euvolemic rats (27). Although nonspecific effects of ASA on, for example, the enzymes phospholipase $A_{2}$ and/or 5-LO cannot be excluded, the inhibitory effect of ASA on pLT biosynthesis could be explained by a mechanism described earlier for 15S-HETE, which serves as a substrate for the 5-LO (28), namely, that ASA-triggered $15 R$-HETE conversion by leukocyte 5-LO blocks LT formation and switches to 15-epi-LX. This notion is supported by the result that ASA but not sodium salycilate blocks gastric pLT release in rats, suggesting that acetylation is a key event in blocking pLT formation (27).

The finding that ATL possess marked biological activity is of interest (Figs. 6 and 7; Table 1). Recently, we found that 15 -epi-LXA 4 prevents LTB $_{4}$-induced adhesion of PMN to endothelial cells (4). The present results indicate that 15 -epiLXs, in particular 15-epi- $\mathrm{LXB}_{4}$, are also potent inhibitors of airway epithelial cell (Figs. 6 and 7) as well as fibroblast proliferation (see Results). Lungs are exposed to noxious insults (including carcinogens) that cause leukocyte infiltration, mucosecretory and squamous differentiation, and proliferation of epithelial cells and fibroblasts (29). During the course of this process, several pro-inflammatory (i.e., PGs and LTs) and antiinflammatory (i.e., LXs) mediators are likely to be produced via the PGHS and/or LO pathways within the microenvironment. These eicosanoids can exert either stimulatory or inhibitory effects on cell proliferation. pLT, for instance, not only influence epithelial permeability, which can enhance leukocyte migration as well as antigen and mitogen accumulation, but also promote epithelial cell growth (20). ASA, although a wellknown blocker of PG biosynthesis, suppresses cell proliferation by unknown mechanisms. Our findings indicating that ASA is responsible for both inhibition of pLT biosynthesis and formation of LXs and 15-epi-LXs (Fig. 5) draw attention to a potential role for these LO-derived eicosanoids in mediating ASA's antiproliferative properties. Along these lines, we have examined ATL's ability to stimulate an increase in intracellular cAMP level with the A549 cells. These compounds did not, however, stimulate accumulation of cAMP in these cells (data not shown). Thus, the cellular site(s) of action for ATL's antiproliferative action remain to be identified.

Evidence is also accumulating that pulmonary cell phenotype changes are also regulated by pleotropic mediators such as IL- $1 \beta$, which has proven to inhibit epithelial cell proliferation (30). Our observation that IL-1 $\beta$ stimulates PGHS-2 enzymes as well as 15R-HETE generation in 
A549 (Fig. 1 and 2), thereby providing substrate for leukocyte formation of 15-epi-LXs, suggests that the combination of cytokine gene regulation and PGHS- 2 regulation together with ASA could enhance the antineoplastic properties noted for this drug. Although additional work is needed to define further the physiologic and pathophysiologic roles of ATL in vivo, the results of the present investigation suggest the intriguing possibility that formation of 15 -epi-LX that display antiproliferative properties (Figs. 6 and 7) may be relevant in ASA's preventive role against human lung and breast cancers (31). Also, the formation of 15-epi-LXs, in particular 15-epi- $\mathrm{LXB}_{4}$, could be a component in ASA's protective effect against colorectal neoplasia (5), a setting where intestinal epithelial PGHS-2 expression is known to be up-regulated (32). Since the therapeutic effect of ASA in lowering the risk of cancer was apparent at long durations, in most cases greater than 2 years of treatment (31), it is possible that the generation of LX and their impact in cell proliferation noted in vitro (Figs. 6 and 7; Table 1) may have a cumulative action within the microenvironment in vivo.

In summary, the present results demonstrate that costimulation of epithelial cells and PMN in the presence of ASA leads to the formation of

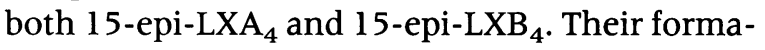
tion involves both epithelial ASA-acetylated PGHS-2 and cytochrome P450-derived 15RHETE that is substrate for leukocyte 5-LO via transcellular events. The finding that $\mathrm{P} 450$ can also initiate 15-epi-LX suggests that these compounds can be generated in tissues with $\mathrm{P} 450$ activity without requiring ASA triggering and raises the possibility that 15 -epi-LX can be generated de novo, and their pathways of formation are enhanced by the presence of ASA. A potent antiproliferative effect of 15-epi-LXs was established in vitro with cultured cells (Fig. 7 and Table 1), which now suggests that formation of these novel eicosanoids may have implications in ASA's protective effect against human cancer.

\section{ACKNOWLEDGMENTS}

We thank Prof. N. Petasis (Department of Chemistry, University of Southern California) for providing reference samples of synthetic 15-epiLXA $_{4}$-methyl ester and $M$. Halm Small for assistance in manuscript preparation. These studies were supported by National Institutes of Health Grants GM38765 and P01-DK50305
(CNS). JC was the recipient of a Fulbright/Spanish Ministry of Education and Science (MEC) fellowship during the present experiments.

\section{REFERENCES}

1. Elias JA, Zheng T, Einarsson O, et al. (1994) Epithelial interleukin-11. Regulation by cytokines, respiratory syncytial virus, and retinoic acid. J. Biol. Chem. 269: 22261-22268.

2. Samuelsson B, Dahlén SE, Lindgren JÅ, Rouzer CA, Serhan CN. (1987) Leukotrienes and lipoxins: Structures, biosynthesis, and biological effects. Science 237: 1171-1176.

3. Serhan CN. (1994) Lipoxin biosynthesis and its impact in inflammatory and vascular events. Biochim. Biophys. Acta 1212: 1-25.

4. Clària J, Serhan CN. (1995) Aspirin triggers previously undescribed bioactive eicosanoids by human endothelial cell-leukocyte interactions. Proc. Natl. Acad. Sci. U.S.A. 92: 94759479.

5. Giovannucci E, Egan KM, Hunter DJ, et al. (1995) Aspirin and the risk of colorectal cancer in women. N. Engl. J. Med. 333: 609-614.

6. Marnett LJ. (1992) Aspirin and the potential role of prostaglandins in colon cancer. Cancer Res. 52: 5575-5589.

7. Marcus AJ. (1995) Aspirin as prophylaxis against colorectal cancer. $N$. Engl. J. Med. 333: 656-658.

8. Lieber M, Smith B, Szakal A, Nelson-Rees W, Todaro G. (1976) A continuous tumor-cell line from a human lung carcinoma with properties of type II alveolar epithelial cells. Int. J. Cancer 17: 62-70.

9. Böyum A. (1968) Isolation of mononuclear cells and granulocytes from human blood. Isolation of mononuclear cells by one centrifugation, and of granulocytes by combining centrifugation and sedimentation at $1 \mathrm{~g}$. Scand. J. Clin. Lab. Invest. 21 (Suppl 97): 7789.

10. Muerhoff AS, Williams DE, Reich NO, CaJacob CA, Ortiz de Montellano PR, Masters BSS. (1989) Prostaglandin and fatty acid $\omega$ and $(\omega-1)$-oxidation in rabbit lung: Acetylenic fatty acid mechanism-based inactivators as specific inhibitors. J. Biol. Chem. 244: 749-756.

11. Hawkins DJ, Kühn H, Petty EH, Brash AR. (1988) Resolution of enantiomers of hydroxyeicosatetraenoate derivatives by chiral 
phase high-pressure liquid chromatography. Anal. Biochem. 173: 456-462.

12. Hla T, Neilson K. (1992) Human cyclooxygenase-2 cDNA. Proc. Natl. Acad. Sci. U.S.A. 89: 7384-7388.

13. Sigal E, Craik CS, Highland E, et al. (1988) Molecular cloning and primary structure of human 15-lipoxygenase. Biochem. Biophys. Res. Commun. 157: 457-464.

14. Funk CD, FitzGerald GA. (1991) Eicosanoid forming enzyme mRNA in human tissues. J. Biol. Chem. 266: 12508-12513.

15. Dixon RAF, Jones RE, Diehl RE, Bennett CD, Kargman S, Rouzer CA. (1988) Cloning of the cDNA for human 5-lipoxygenase. Proc. Natl. Acad. Sci. U.S.A. 85: 416-420.

16. Marshall NJ, Goodwin CJ, Holt SJ. (1995) A critical assessment of the use of microculture tetrazolium assays to measure cell growth and function. Growth Regul. 5: 69-84.

17. Cybulsky AV, Goodyer PR, Cyr M-D, McTavish AJ. (1992) Eicosanoids enhance epidermal growth factor receptor activation and proliferation in glomerular epithelial cells. Am. J. Physiol. 262(Renal Fluid Electrolyte Physiol. 31): F639-F646.

18. Holtzman MJ, Turk J, Shornick LP. (1992) Identification of a pharmacologically distinct prostaglandin $\mathrm{H}$ synthase in cultured epithelial cells. J. Biol. Chem. 267: 21438-21445.

19. Nicolaou $\mathrm{KC}$, Marron BE, Veale CA, et al. (1989) Identification of a novel 7-cis-11trans-lipoxin $\mathrm{A}_{4}$ generated by human neutrophils: total synthesis, spasmogenic activities and comparison with other geometric isomers of lipoxins $\mathrm{A}_{4}$ and $\mathrm{B}_{4}$. Biochim. Biophys. Acta 1003: 44-53.

20. Baud L, Sraer J, Perez J, Nivez M-P, Ardaillou R. (1985) Leukotriene $C_{4}$ binds to human glomerular epithelial cells and promotes their proliferation in vitro. J. Clin. Invest. 76: 374-377.

21. Alley MC, Scudiero DA, Monks A, et al. (1988) Feasibility of drug screening with panels of human tumor cell lines using a microculture tetrazolium assay. Cancer Res. 48: $589-601$.

22. Croxtall JD, Flower RJ. (1992) Lipocortin 1 mediates dexamethasone-induced growth arrest of the A549 lung adenocarcinoma cell line. Proc. Natl. Acad. Sci. U.S.A. 89: 35713575.

23. Herschman HR. (1996) Prostaglandin synthase 2. Biochim. Biophys. Acta 1299: 125140.

24. Capdevila J, Yadagiri P, Manna S, Falck JR. (1986) Absolute configuration of the hydroxyeicosatetraenoic acids (HETEs) formed during catalytic oxygenation of arachidonic acid by microsomal cytochrome P-450. Biochem. Biophys. Res. Commun. 141: 1007-1011.

25. Vogel C, Dohr O, Abel J. (1994) Transforming growth factor- $\beta_{1}$ inhibits TCDD-induced cytochrome P450IAl expression in human lung cancer A549 cells. Arch. Toxicol. 68: 303-307.

26. Pankow D, Damme B, Schror K. (1994) Acetylsalicylic acid-Inducer of cytochrome P-450 2E1? Arch. Toxicol. 68: 261-265.

27. Peskar BM, Hoppe U, Lange K, Peskar BA. (1988) Effects of non-steroidal anti-inflammatory drugs on rat gastric mucosal leukotriene $\mathrm{C}_{4}$ and prostanoid release: relation to ethanol-induced injury. Br. J. Pharmacol. 93: 937-943.

28. Serhan CN. (1989) On the relationship between leukotriene and lipoxin production by human neutrophils: Evidence for differential metabolism of 15-HETE and 5-HETE. Biochim. Biophys. Acta 1004: 158-168.

29. Jetten AM. (1991) Growth and differentiation factors in tracheobronchial epithelium. Am. J. Physiol. 260(Lung Cell Mol. Physiol. 4): L361-L373.

30. Nakane $T$, Szentendrei $T$, Stern $L$, Virmani M, Seely J, Kunos G. (1990) Effects of IL-1 and cortisol on $\beta$-adrenergic receptors, cell proliferation, and differentiation in cultured human A549 lung tumor cells. J. Immunol. 145: $260-266$.

31. Schreinemachers DM, Everson RB. (1994) Aspirin use and lung, colon, and breast cancer incidence in a prospective study. Epidemiology 5: 138-146.

32. Eberhart CE, Coffey RJ, Radhika A, Giardiello FM, Ferrenbach S, Dubois RN. (1994) Up-regulation of cyclooxygenase 2 gene expression in human colorectal adenomas and adenocarcinomas. Gastroenterology 107: 1183-1188. 